\title{
Chromium content of lungs of chromate workers with lung cancer
}

\author{
YASUHIRO TSUNETA, YUTAKA OHSAKI, KIYONOBU KIMURA, HIROSHI MIKAMI, \\ SHOSAKU ABE, AND MAKOTO MURAO
}

From the First Department of Medicine, Faculty of Medicine, Hokkaido University, Sapporo, Japan

ABSTRACT The chromium content was measured in the lungs of chromate workers, obtained at + necropsy in six patients and at surgery in two. The mean chromium content of peripheral lung tissue $\mathbb{C}_{\infty}$ was $36.7 \mu \mathrm{g}$ per gm wet weight (range 0.50 to $130.2 \mu \mathrm{g}$ ) and that of the large airways was $0.51 \mu \mathrm{g}_{\mathrm{O}}$ per gm wet weight (range 0.22 to $0.99 \mu \mathrm{g}$ ). These mean values were high compared with those from $\rightarrow$ control lungs of a non-chromate exposed lung cancer patient-respectively $0.21 \mu \mathrm{g}$ per gm in lung tissue and $0 \cdot 11 \mu \mathrm{g}$ per gm in the large bronchi. The longer the exposure period, the higher was the chromium content in the lungs. The concentration of chromium in the upper lobes was significantly $\vec{\varphi}_{0}$ higher than that in the lower lobes, suggesting regional differences either in clearance from oro deposition in the lung. Moreover, it was apparent that the metal remained in the lungs long aftero exposure to chromate had ceased.

Chromate lung cancer has been recognised as one of the occupational diseases since the first report by Pfeil in $1935^{1}$ and other reports in Germany and America. In Japan, chromate lung cancer was reported by Ohsaki in $1978 .^{2}$ Although chromate compounds have been incriminated as carcinogens details of the exposure period for induction of lung cancer and of the chromate content in the body are not well documented. We measured the chromium content of the lungs, obtained at surgery and necropsy, of lung cancer patients who had worked in the chromate industry.

\section{Methods}

The lungs of eight chromate workers were obtained, in two cases at surgery and in six at necropsy (table 1). All the patients were men and the average age was 58.5 years (range 50 to $72 \mathrm{yr}$ ). All but one patient had nasal perforation. Histology revealed squamous cell carcinoma in six cases, small cell anaplastic carcinoma in one case, and adenocarcinoma in one case. The mean latent period between the occurrence of lung cancer and leaving work was five years, ranging from 0 to 27 years.

Address for reprint requests: Dr Y Ohsaki, First Department of Medicine, Faculty of Medicine, Hokkaido University, North 14, West 5, Sapporo, Japan.
METHOD OF MEASUREMENT

After measuring the wet weight of lung tissue, $\stackrel{\vec{A}}{\vec{A}}$ cut into small pieces with a knife, $1 \mathrm{ml}$ of nitric 3 acid per gm was added to the tissue and heated? to boiling point on a hot plate. Thereafter, it wasọ. mineralised with a mixture of nitric, sulphuric, and perchloric acids in the ratio of $3: 1: 1$. Aftero decomposition and drying, the sample was dissolved in $1 \mathrm{~N}$ nitric acid, then $\mathrm{K}_{2} \mathrm{SO}_{4}$ was addedo and made into a $500 \mathrm{ppm}$ solution to stabilise the chromium solution. Measurement of the materialo was performed with a flameless atomic absorption spectrophotometer with carbon rod atomisero (Variant-Tectron Co Model AA-1000 Type). ${ }^{3}$ The following conditions of photometry were used:을. electric current of lamp $3 \mathrm{~mA}$, electric vôltage of photomal $490 \mathrm{~V}$, wave length of measurement ${ }^{\circ}$ $357.8 \mathrm{~nm}$, slit width $0.2 \mathrm{~nm}$. Background noise could be ignored. The conditions for the carbon rod atomiser was as follows: electric voltage ando time for drying $1.4 \mathrm{~V}$ and 14.5 seconds, for ashingo $3.2 \mathrm{~V}$ and 14.0 seconds, for atomising $8.0 \mathrm{~V}$ and $2 \cdot 6$ seconds, respectively. The cooling time of the + ? carbon rod atomiser was 60 seconds.

To test the recovery of chromium, the concentration of chromium which was added to the livero of mongrel dogs was measured. None, $0 \cdot 1 \mu \mathrm{g} / 1, \mathbb{\mathbb { Q }}$ or $0.2 \mu \mathrm{g} / 1$ of standard chromium solution re-spectively were added to the liver, and a parallel $\delta$ relationship with the calibration curve of standardo 
Table 1 Profile of subjects

\begin{tabular}{|c|c|c|c|c|c|c|c|c|}
\hline Number & Name & Sex & $\begin{array}{l}\text { Age } \\
(y r)\end{array}$ & $\begin{array}{l}\text { Smoking history } \\
\text { (number of cigarettes } \\
\text { per day } \times \text { years) }\end{array}$ & $\begin{array}{l}\text { Exposure period } \\
(y r)^{*}\end{array}$ & $\begin{array}{l}\text { Latent period } \\
(y r)\end{array}$ & $\begin{array}{l}\text { Perforation } \\
\text { of the nasal } \\
\text { septum }\end{array}$ & Histology \\
\hline $\begin{array}{l}1 \\
2 \\
3 \\
3 \\
4 \\
5 \\
6 \\
7 \\
8\end{array}$ & $\begin{array}{l}\text { MT } \\
\text { MI } \\
\text { NK } \\
\text { KH } \\
\text { SY } \\
\text { HH } \\
\text { SI } \\
\text { JO }\end{array}$ & $\begin{array}{l}\mathbf{M} \\
\mathbf{M} \\
\mathbf{M} \\
\mathbf{M} \\
\mathbf{M} \\
\mathbf{M} \\
\mathbf{M} \\
\mathbf{M}\end{array}$ & $\begin{array}{l}67 \\
54 \\
50 \\
50 \\
59 \\
57 \\
59 \\
72\end{array}$ & $\begin{array}{l}30 \times 40 \\
20 \times 20 \\
25 \times 20 \\
25 \times 30 \\
20 \times 20 \\
10 \times 40 \\
30 \times 30 \\
20 \times 50\end{array}$ & $\begin{array}{l}8(8) \\
22(21) \\
25(25) \\
25(25) \\
28(27) \\
28(24) \\
29(28) \\
32(?)\end{array}$ & $\begin{array}{l}27 \cdot 6 \\
1 \cdot 0 \\
1 \cdot 3 \\
0 \\
1 \cdot 4 \\
0 \\
0 \\
12 \cdot 0\end{array}$ & $\begin{array}{l}(+) \\
(+) \\
(+) \\
(+) \\
(+) \\
(+) \\
(+) \\
(-)\end{array}$ & $\begin{array}{l}\text { Epidermoid ca } \\
\text { Oat cell ca } \\
\text { Epidermoid ca } \\
\text { Epidermoid ca } \\
\text { Epidermoid ca } \\
\text { Epidermoid ca } \\
\text { Epidermoid ca } \\
\text { Adeno ca }\end{array}$ \\
\hline
\end{tabular}

* Period of heavy exposure to chromium.

solution of chromium was found. Recovery rate was from $107 \cdot 7$ to $115.3 \%$. The difference between the chromium content of the liver and the standard solution would be the chromium present in normal liver. Analyses were repeated three times and the mean value was used. As a control, the lung of a non-chromate exposed lung cancer patient was analysed in the same way.

\section{OCCUPATION OF SUBJECTS}

The factory was small and the subjects had worked in all parts of the chromium industry. We divided the working place as in fig 1 , processes $I$,

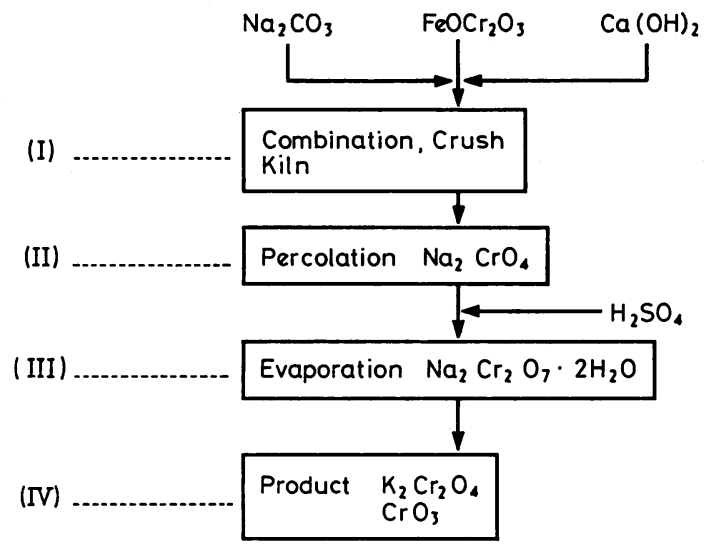

(V)

Electric furnace, brick making

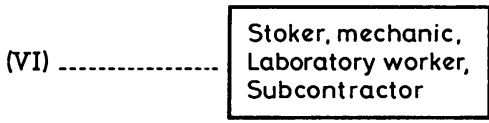

(VII) .................. Office worker

Fig 1 Manufacturing process in the chromate producing factory.
II, III, and IV being the most hazardous for chromium dust exposure. We did not know exposure levels in individual subjects but they had worked in the industry for between eight and 32 years, with a mean exposure time of $24 \cdot 6$ years.

\section{Results}

CHROMIUM CONTENT OF THE LUNGS (TABLE 2)

The chromium content of airways, lung tissue, and tumour itself was markedly higher in the patients than the values in the control lung. Taking the right upper lobe, for instance, the mean concentration was $51.7 \mu \mathrm{g}$ per gm wet weight, 114 times higher than the control value. In the right lower lobe, on the other hand, the mean content was $21.3 \mu \mathrm{g}$ per gm wet weight. Although this value was much higher than the control value of $0.3 \mu \mathrm{g}$ it was less than the concentration in the upper lobes. Although the chromium content of the large airways was higher than that of the control, the differences were not so striking as in the lung tissue. When the chromium concentration of the upper lobe was compared with that of the lower lobe, there was a significant difference $(p<0.02$, fig 2$)$.

\section{RELATIONSHIP BETWEEN CHROMIUM CONTENT AND EXPOSURE PERIOD}

The longer the period of exposure to chromates, the higher was the concentration of chromium in the lungs (fig 3 ). This tendency was evident only in the lung tissue and not in the large airways. In the upper lobes the correlation between chromium content and exposure period was significant $(r=0.831, p<0.01)$.

\section{Discussion}

Workers in the chromate industry are exposed to various dusts, such as chromate containing insoluble hexavalent chrome, in addition to lime and sulphuric acid during the process to the final 
Table 2 Concentration of chromium in the lung ( $\mu \mathrm{g} / \mathrm{g}$ wet weight)

\begin{tabular}{|c|c|c|c|c|c|c|c|c|c|c|c|}
\hline Number & Name & Larynx & Trachea & $M b r$ & $R U L$ & $R M L$ & $R L L$ & $L U L$ & $L L L$ & Tumour & $M L N$ \\
\hline 1 & MT & & 0.22 & & 2.57 & 1.67 & 0.50 & & 0.73 & 0.39 & 0.98 \\
\hline 2 & MI & & & & 20.45 & & 7.69 & & 4.79 & $6 \cdot 28$ & \\
\hline 3 & NK & $0 \cdot 35$ & $0 \cdot 37$ & 0.40 & $42 \cdot 61$ & $50 \cdot 84$ & $64 \cdot 38$ & $132 \cdot 20$ & & & \\
\hline 4 & KH & 0.79 & 0.42 & & $66 \cdot 38$ & & 18.66 & & & & \\
\hline 5 & SY & & & & & & & $56 \cdot 16$ & & & \\
\hline 6 & $\mathrm{HH}$ & & & & $74 \cdot 42$ & & & & & & \\
\hline 7 & SI & & 0.99 & & 103.90 & & $10 \cdot 10$ & & & & 0.06 \\
\hline 8 & JO & & & & & & $26 \cdot 44$ & & & & $69 \cdot 38$ \\
\hline Control & & & $0 \cdot 11$ & & 0.45 & 0.11 & 0.30 & 0.08 & $0 \cdot 14$ & & \\
\hline
\end{tabular}

$\mathrm{M}$ br = main bronchus, $\mathrm{RUL}=$ right upper lobe, $\mathrm{RML}=$ right middle lobe, $\mathrm{RLL}=$ right lower lobe, $\mathrm{LUL}=$ left upper lobe,

LLL = left lower lobe, MLN = mediastinal lymphnode.

product. Inhaled dusts are cleared from airways by means of physical mechanisms at first. Dusts reaching the small airways are eliminated by mucociliary escalator and alveolar macrophages, but excessive amounts of dust may be deposited in the lungs. ${ }^{45}$ In addition to the amount of dust, depressing of clearance mechanisms may be a factor in causing inhalational diseases. Our results reveal retention of chromium for a long time, even after leaving work. In one patient who had been away from the work place for 30 years, the chromium concentration was between two and nine times higher than the control value. Retention of chromium is mainly in the lung tissue. Concentration of chromium in the large airways is not so high nor is concentration in the tumour itself. Presumably expansion of the tumour would

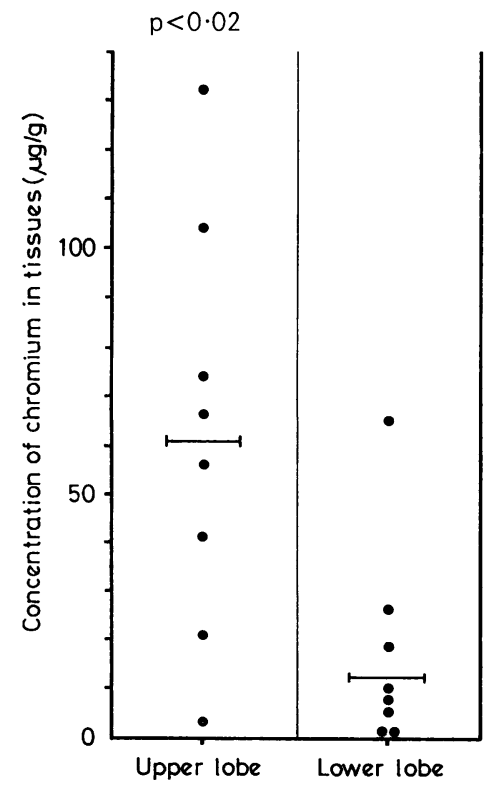

Fig 2 Regional difference of chromium content in the lungs. replace lung tissue containing concentrated chromium.

Our patients were all heavy smokers, so that $\stackrel{\circ}{工}$ suppression of clearance mechanisms by smoking might have been a factor in the retention of $\frac{D}{0}$ chromium in the lungs. Smoking is an important factor in suppressing the clearance mechanisms, $\vec{\oplus}$ altering ciliary action, and the function of macrophages and pulmonary immunological defence mechanisms. ${ }^{6}$

Soluble chromate containing hexavalent chrome is said to be more potent than insoluble trivalent chrome is a carcinogen. ${ }^{7}$ However, there $\stackrel{\circ}{\mathbb{}}$ are several reports questioning this and the problem is not solved yet. ${ }^{8}$ Our method measured chrome in the tissue as a whole, so that we could not investigate the difference in carcinogenicity of trivalent and hexavalent chrome. Our results indicate regional differences of chromium concentration in the lungs, the concentration being significantly higher in the upper lobes although the primary site of the lung cancer was mainly the

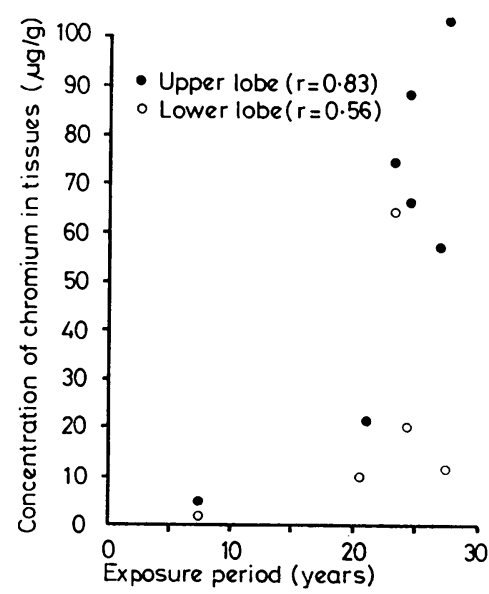

Fig 3 Relationship between exposure period and chromium concentration in the lungs. 
lower lobe. There is more ventilation in the lower than in the upper lobe, ${ }^{9}$ so the volume of dust cntering the lower lobe could be greater. On the other hand, blood flow and distensibility is less in the upper lobe. Thus there could be less effective clearance of the upper lobes, and this could explain the regional differences in chromium content.

Chromium content in our patients was much higher than in a control patient, even a long time after leaving the working place. When chromate dust is deposited in lung tissue, its excretion is very slow. Taylor ${ }^{10}$ reported the relationship between duration of chromate exposure and induction of lung cancer. Taking patients with exposure periods of five to nine years, the induction rate of lung cancer measured 106.2 person per 100000 ; however, the rate went up to 400 per 100000 when subjects with exposure periods of 20 to 24 years were included. It is clear that the longer the exposure period to chromate dust, the higher the incidence of lung cancer.

\section{References}

1 Pfeil E. Lungentumoren als Berufserkrankung in Chromatbetrieben. Dtsch Med Wochenshr 1935; 61:1197-200.
2 Ohsaki Y, Abe S, Kimura K, Tsuneta Y, Mikami H, Murao M. Lung cancer in Japanese chromate workers. Thorax 1978; 33:372-4.

3 Feldman FG, Knoblock EC, Purdy WC. The determination of chromium in biological materials by atomic absorption spectroscopy. Anal Chim Acta 1967; 38:489-97.

4 Mitchell RI. Retention of aerosol particles in the respiratory tract. Am Rev Respir Dis 1960; 82: 627-39.

5 Lauweryns JM, Baert JH. Alveolar clearance and the role of the pulmonary lymphatics $A m$ Rev Respir Dis 1977; 115:625-83.

6 Green GM, Jakab GJ, Low RB, Davis GS. Defence mechanisms of the respiratory membrane. Am Rev Respir Dis 1977; 115:479-514.

7 Baetjer AM, Damron C, Budacz V. The distribution and retention of chromium in men and animals. Arch Ind Health 1959; 20:136-54.

8 Hueper WC. Occupational and environmental cancers of the respiratory system. Berlin: Springer, 1966.

9 West JB. (ed.). Regional differences in the lung. New York: Academic Press, 1977.

10 Taylor J. The relationship of mortality and duration of employment as reflected by a cohort of chromate workers. Am J Public Health 1966; 56:218-29. 